\title{
Ethnomedicinal plants used by Adi community of Upper Siang District of Arunachal Pradesh in North-East India
}

\author{
Om Prakash Arya ${ }^{1,4}$, Wishfully Mylliemngap ${ }^{1}$ and Anita Pandey ${ }^{2,3}$ \\ ${ }^{1}$ North-East Regional Centre, G.B. Pant National Institute of Himalayan Environment, Itanagar - 791113, \\ Arunachal Pradesh, India. \\ ${ }^{2}$ Centre for Environmental Assessment and Climate Change, G.B. Pant National Institute of Himalayan \\ Environment, Kosi-Katarmal, Almora 263643, Uttarakhand, India. \\ ${ }^{3}$ Department of Biotechnology, Graphic Era (Deemed to be) University, Dehradun-248002, Uttarakhand, India \\ ${ }^{4}$ Communicating author, e-mail: omey89@gmail.com
}

[Received 07.12.2020; Revised 23.12.2020: Accepted 29.12.2020; Published 31.12.2020]

\begin{abstract}
The present study revealed rich ethnobotanical knowledge on utilization of medicinal plants in traditional healthcare system of indigenous communities from remote villages of Upper Siang district, Arunachal Pradesh. Thirty-eight ethnomedicinal plant species belonging to 36 genera and 26 families were reported from the study area, with Asteraceae as the most dominant family and herbs as dominant life-forms. Leaves were the most frequently used plant parts while flowers were least used in preparation of medicine. The most common forms of medicinal preparations were paste form followed by cooked, raw (direct consumption) and as decoction. Apart from medicinal uses, the recorded plants were also used as edible fruits, vegetables, spices and condiments, hunting and fishing. The present study would serve as a tool for identifying important medicinal plant species for further pharmacological research, scientific validation, and for initiating appropriate conservation measures for sustainable utilization.
\end{abstract}

Key words: Adi community; Upper Siang; Traditional medicine, Eastern Himalaya

\section{INTRODUCTION}

Plants are important sources of therapeutic drugs and play a significant role in the survival of the tribal and ethnic communities. Nearly $80 \%$ of the rural people in the developing countries primarily rely on traditional medicine to meet their primary health care needs (WHO 2001). The medicinal plants have traditionally played an important role in the socio-cultural, spiritual and medicinal arena of the local communities of Eastern Himalaya (Arya et al. 2017). In the North-East India, several reports are available on medicinal plants species used in traditional healthcare practices by different tribal communities for treatment of minor and major ailments (Chakraborty et al. 2012). The state of Arunachal Pradesh covers a major portion of the Indian Eastern Himalaya with a geographical area of $83,743 \mathrm{sq} . \mathrm{km}$. It comprises a part of the IndoBurma global biodiversity hotspot (Myers et al. 2000). The distinct geographical location and climatic condition makes it an ideal repository of a rich biodiversity including medicinal plants (Doley et al. 2010; Sati et al. 2012). Arunachal Pradesh is estimated to contain nearly 50\% of the total flowering plant species in India and over 500 species of medicinal plants have been reported so far (Rao \& Hajra 1986; Haridasan et al. 2003). However, the region is still largely remained unexplored due to step topography and inclement weather events.

The critical literature search revealed that ethnomedicinal plants species used by different indigenous communities of Arunachal Pradesh for treatment of various types of diseases/ disorders have been largely reported from tropical and subtropical regions (Doley et al. 2010; Ghosh et al. 2014; Shankar \& Rawat 2008). In Upper Siang district, only few discrete studies 
were available from different pockets of the district including Dehang-Debang Biosphere Reserve (DDBR) (Kagyung et al. 2010), Daying Ering Wildlife Sanctuary (Jeyaprakash et al. 2017) and Yingkiong and Maryang valleys (Danggen et al. 2018). From these studies, it was observed that the knowledge and utilization pattern of ethnomedicinal plants by the local communities differ from one place to another even within the same district. The present study was undertaken to document the ethnobotanical knowledge and utilization of medicinal plants in traditional healthcare systems of the Adi community residing in Upper Siang district of Arunachal Pradesh. The resulting database would be helpful in prioritization of important medicinal plants of the study area for scientific validation studies.

\section{MATERIALS AND METHODS}

\section{Study area}

The study was conducted in Upper Siang District, Arunachal Pradesh which lies within a geographical coordinate between $28^{\circ} 09^{\prime} 09^{\prime \prime} \mathrm{N}$ to $29^{\circ} 19^{\prime} 10^{\prime \prime} \mathrm{N}$ Latitude and $94^{\circ} 17^{\prime} 36^{\prime \prime} \mathrm{E}$ to $95^{\circ} 25^{\prime} 35^{\prime \prime}$ E Longitude, covering a geographical area of $6188 \mathrm{sq} . \mathrm{km}$. The district mainly comprises of three climatic zones, viz., tropical (300-900 $\mathrm{m}$ asl), subtropical (900-1500 m asl) and sub-temperate (>1500 m asl) (Choudhary et al. 2012). The district has been divided into 11 administrative circles and has a total population of 35,320 (9). The majority of the population belong to Adi tribe while the other tribes like Memba, Khamba and Idu-Mishmi are also found to inhibit the region. Six villages, viz., Gobuk, Moying, Simong, Haleng, Karko and Gette, situated within an altitudinal range of $404 \mathrm{~m}$ to $1201 \mathrm{~m}$ asl (Figure 1) were covered in the present study. Among the surveyed villages, Simong has the highest population with 179 households and a total population of 672 . Haleng was the smallest village with 19 households and a population of 50 people.

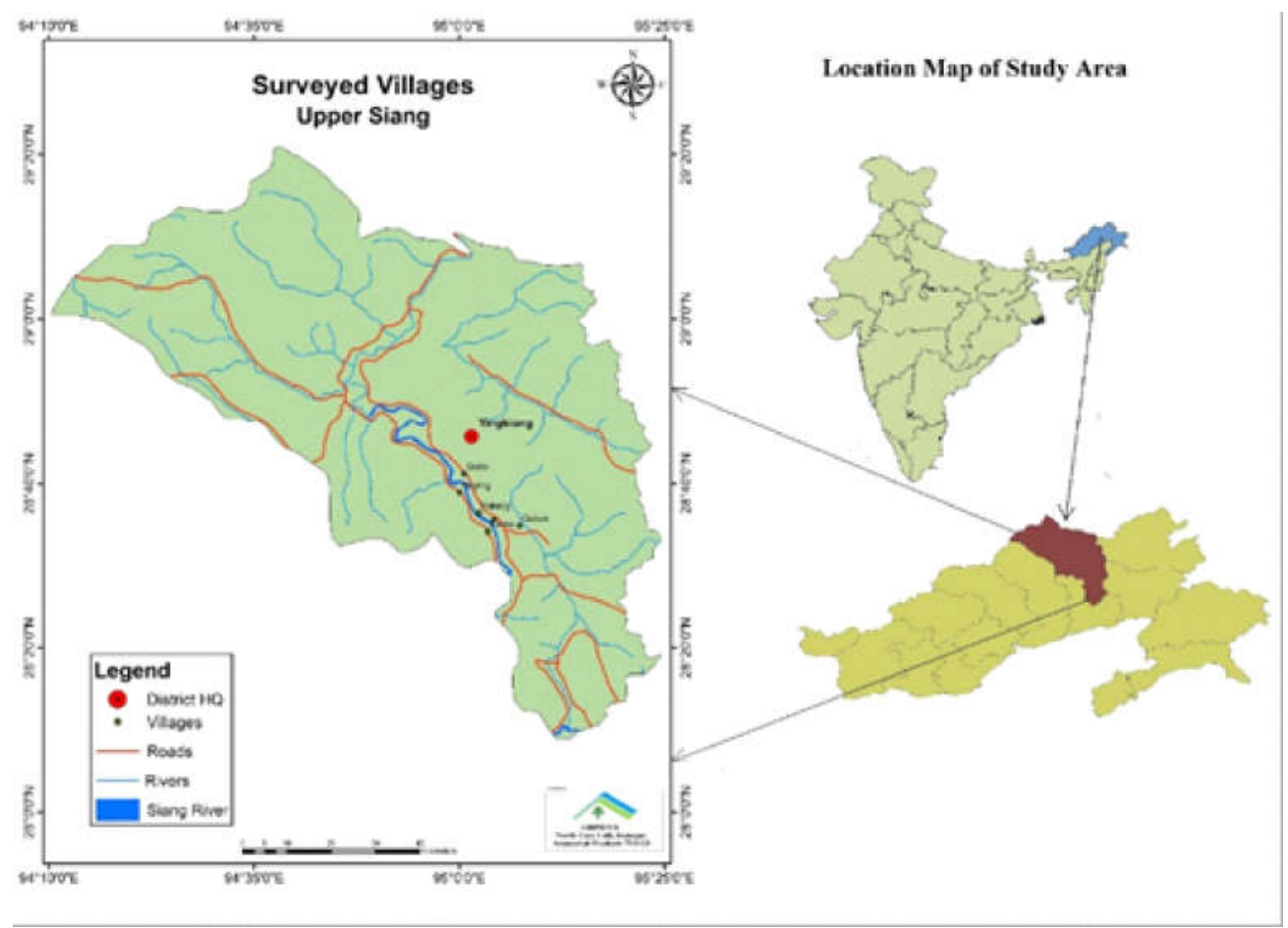

Figure 1. Location map showing the study area with pointed locations of surveyed villages 


\section{Data collection}

The study was conducted through interaction with local knowledgeable persons of the surveyed villages from different age-groups, educational status and profession. Snowball sampling approach (Johnson 2014) was used in selection of informants for the study. The Headmen (Gao Burah) of the respective villages were consulted and Prior Information Consent (PIC) was obtained for conducting interview with the villagers. The Headman (Gao Burab) and Traditional Medical Practitioners (TMP) of the target villages were identified as Key informants due to their age, present or previous ethnomedicinal practices and experiences. The selected Key informants were again asked to identify other persons of their village who may be able to provide substantial information related to plant based ethnomedicinal knowledge. All the informants were previously explained about the purpose and objectives of the study and prior informed consent (PIC) was obtained from each informant before proceeding with the interviews and group discussions. Only those persons who agreed to take part in the questionnaire interviews were taken as informants and detail information regarding their name, village, age, gender, occupation, education and signature were entered in the datasheets.

Altogether 139 informants comprising of 86 males and 53 females were interviewed during the study. All the informants were categorised into 6 different age-groups: 25 - 35, 35 - 45, 45 - 55, 55 - 65, 65 - 75 and >75 years old. Majority of informants belong to the age group of $55-65$ years and least number from the $>75$ years age group (Figure 2). Information was collected from informants using open-ended questionnaires, semi-structured interviews and focussed group discussions. The questionnaires contain questions about name of the medicinal plants, traditional uses, habit, availability (common/rare), source of collection (cultivated/wild), parts used, mode of administration, and also if any conservation efforts were being adopted by the villagers or the government. Field surveys were also conducted around the village and nearby forest areas with the local informants for correct identification and collection of medicinal plants used by them. The ethnomedicinal plant species were identified by consultation of herbarium materials and experts at Botanical Survey of India, Arunachal Pradesh Regional Centre, Itanagar and State Forest Research Institute, Itanagar.

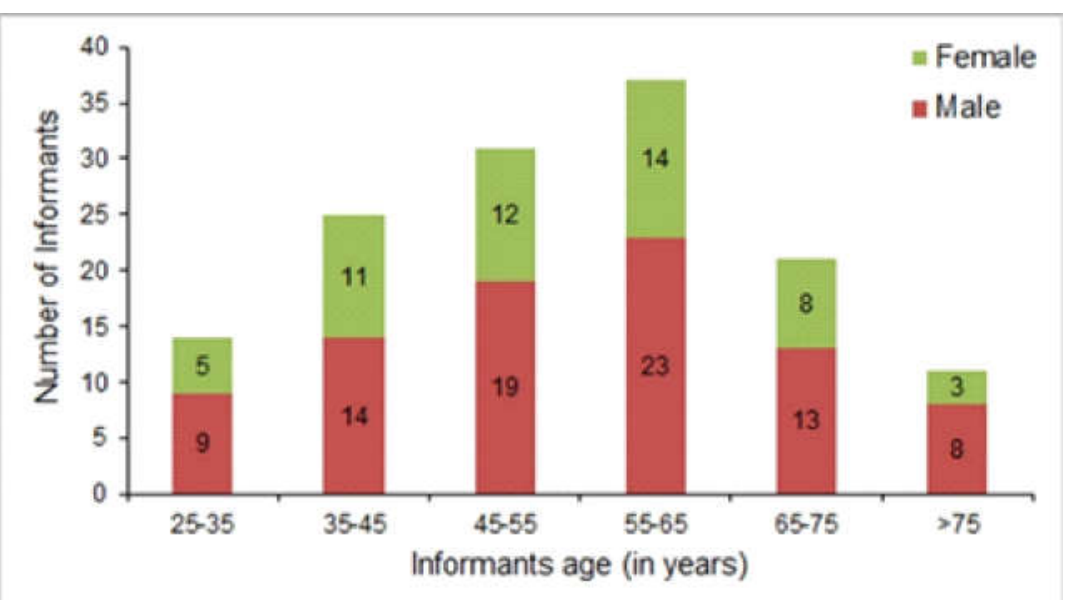

Figure 2. Number and age-group of informants interviewed during the survey

\section{RESULTS}

\section{Diversity of ethnomedicinal plants}

Present investigation has revealed a total of 38 species of ethnomedicinal plants belonging to 36 genera and 26 families used by the indigenous Adi communities of Upper Siang District of 
Arunachal Pradesh (Table 1). Asteraceae was found to be the most dominant family of ethnomedicinal plants recorded from the study area, which was followed by Ranunculaceae, and Solanaceae and Oxalidaceae (Figure 3). The remaining 22 families were represented by a single species only. The maximum number of species recorded were herbs $(50 \%)$ followed by shrubs, trees and climbers (Figure 4). The indigenous communities (Adi) of Upper Siang district have been using these plants to treat different types of minor and major diseases and ailments prevalent in the localities which ranging from stomachache, diarrhoea, dysentery, cuts and wounds, burn injuries and toothache to snake bites, malaria, bone fractures and high blood pressure. Apart from medicinal uses, the recorded plants were also reported as wild edible fruits, vegetables, spices and condiments, poison arrows used in hunting large animals and fish poisoning.

Table 1. List of ethnomedicinal plants reported from Upper Siang District, Arunachal Pradesh

\begin{tabular}{|c|c|c|}
\hline $\begin{array}{l}\text { Botanical name [Family]; } \\
\text { Local name; Voucher specimen }\end{array}$ & Habit & Traditional uses \\
\hline $\begin{array}{l}\text { Aconitum ferox Wall. ex Ser. } \\
\text { [Ranunculaceae]; Emo; } \\
\text { GBP/NE/WM-36 }\end{array}$ & Herb & $\begin{array}{l}\text { Rhizome/leaf in the paste form is used as antidote for } \\
\text { snake bite, boil, body pain and swelling. Used as arrow } \\
\text { poison for hunting large animals like bear, tiger }\end{array}$ \\
\hline $\begin{array}{l}\text { Aconitum heterophyllum Wall. ex } \\
\text { Royle [Ranunculaceae]; Emo; } \\
\text { GBP/NE/WM-11 }\end{array}$ & Herb & $\begin{array}{l}\text { Rhizome/leaf in the paste form is used as Antidote for } \\
\text { snake bite, boil, body pain and swelling. Used as arrow } \\
\text { poison for hunting large animals like bear, tiger }\end{array}$ \\
\hline $\begin{array}{l}\text { Ageratum conyzoides L. [Asteraceae]; } \\
\text { Bonger, GBP/NE/OP-06 }\end{array}$ & Herb & Leaf paste is used in the Cuts and wounds \\
\hline $\begin{array}{l}\text { Artemisia nilagitica C.B.Clarke } \\
\text { [Asteraceae]; Pamp; GBP/NE/OP-32 }\end{array}$ & Shrub & $\begin{array}{l}\text { Leaf juice \& paste is used in cough, headache, sores, } \\
\text { wound and nose bleeding }\end{array}$ \\
\hline $\begin{array}{l}\text { Averrhoa carambola L. [Oxalidaceae]; } \\
\text { Kadung; GBP/NE/WM-51 }\end{array}$ & Tree & Juice of the fruits is used in Jaundice \\
\hline $\begin{array}{l}\text { Begonia roxburghii (Miq.) A.DC. } \\
\text { [Begoniaceae]; Babeyaying; } \\
\text { GBP/NE/OP-48 }\end{array}$ & Herb & $\begin{array}{l}\text { Shoot and rhizome in the boiled or raw form is used in } \\
\text { stomach problem, dysentery, diarrhoea }\end{array}$ \\
\hline $\begin{array}{l}\text { Bidens pilosa L. [Asteraceae]; Gomnik; } \\
\text { GBP/NE/OP-25 }\end{array}$ & Herb & $\begin{array}{l}\text { Leaf, seeds and roots are used in cuts and wounds, } \\
\text { ulcers, ear and eye problems; Skin inflammation; } \\
\text { hepatitis, urinary tract infection, malaria, }\end{array}$ \\
\hline $\begin{array}{l}\text { Blumea fistulosa (Roxb.) Kurz } \\
\text { [Asteraceae]; Rumdum; GBP/NE/WM- } \\
13\end{array}$ & Herb & Leaf in the boiled/cooked form is used in Diarrhoea \\
\hline $\begin{array}{l}\text { Campylandra aurantiaca Baker } \\
\text { [Asparagaceae]; Kekong kelong; } \\
\text { GBP/NE/WM-15 }\end{array}$ & Herb & Paste of the root is used in vomiting and headache \\
\hline $\begin{array}{l}\text { Carica papaya L. [Caricaceae]; } \\
\text { GBP/NE/OP-09 }\end{array}$ & Tree & $\begin{array}{l}\text { Mature seeds are crushed and used for fertility control } \\
\text { in Women }\end{array}$ \\
\hline $\begin{array}{l}\text { Castanopsis indica (Roxb. ex Lindl.) } \\
\text { A.DC. [Fagaceae]; Hirang; } \\
\text { GBP/NE/WM-22 }\end{array}$ & Tree & $\begin{array}{l}\text { Paste of the leaves applied to wounds to stop bleeding. } \\
\text { Plants also used in religious festival 'Solung puja'. }\end{array}$ \\
\hline $\begin{array}{l}\text { Centella asiatica (L.) Urban [Apiaceae]; } \\
\text { Loram/ Kipum Yayum; GBP/NE/OP-29 }\end{array}$ & Herb & $\begin{array}{l}\text { Shoots in the raw form are used in Gastric problem, } \\
\text { constipation, blood purification }\end{array}$ \\
\hline $\begin{array}{l}\text { Chromolaena odorata (L.) R.M.King } \\
\text { \& H.Rob [Asteraceae]; Heling; } \\
\text { GBP/NE/WM-44 }\end{array}$ & Shrub & Leaf paste is used in major cuts and wounds \\
\hline
\end{tabular}


Om Prakash Arya et al. 269

\begin{tabular}{|c|c|c|}
\hline $\begin{array}{l}\text { Botanical name [Family]; } \\
\text { Local name; Voucher specimen }\end{array}$ & Habit & Traditional uses \\
\hline $\begin{array}{l}\text { Coptis teeta Wall. [Ranunculaceae]; } \\
\text { Mishmi teeta/ Rinko; GBP/NE/OP-17 }\end{array}$ & Herb & $\begin{array}{l}\text { Decoction of the leaves and roots are used in blood } \\
\text { clotting, stomach trouble, malaria }\end{array}$ \\
\hline $\begin{array}{l}\text { Crassocephalum crepidioides } \\
\text { (Benth.) S. Moore; [Asteraceae]; Gende; } \\
\text { GBP/NE/WM- } 47\end{array}$ & Herb & $\begin{array}{l}\text { Leaf \& tender shoots are boiled and consumed as } \\
\text { vegetable during constipation. The cooked leaf is also } \\
\text { used in insomnia }\end{array}$ \\
\hline $\begin{array}{l}\text { Drymaria cordata (L.) Willd. ex. } \\
\text { Schult. [Caryophyllaceae]; Kaira; } \\
\text { GBP/NE/OP-49 }\end{array}$ & Herb & $\begin{array}{l}\text { Paste of the leaves applied to ringworm and other skin } \\
\text { diseases; bone fracture; leech bite }\end{array}$ \\
\hline $\begin{array}{l}\text { Embelia ribes Burm.f [Myrsinaceae]; } \\
\text { Hingkong; GBP/NE/OP-37 }\end{array}$ & Shrub & $\begin{array}{l}\text { Tender leaves and shoots eaten as cooked vegetable } \\
\text { and is said to act as stomachic }\end{array}$ \\
\hline $\begin{array}{l}\text { Entada scandens (L.) Benth. } \\
\text { [Leguminosae]; Pio-pia/pyopa; } \\
\text { GBP/NE/WM-35 }\end{array}$ & Climber & $\begin{array}{l}\text { Crushed seeds are used in hair wash and as anti- } \\
\text { dandruff. }\end{array}$ \\
\hline $\begin{array}{l}\text { Erigeron bonariensis L. [Asteraceae]; } \\
\text { Daglentado; GBP/NE/WM-16 }\end{array}$ & Herb & Vapour of the leaf is used in Sinusitis problem \\
\hline $\begin{array}{l}\text { Gymnocladus assamicus Kanjilal ex } \\
\text { P.C. Kanjilal [Mimosaceae]; Dekang; } \\
\text { GBP/NE/WM-42/ }\end{array}$ & Tree & $\begin{array}{l}\text { Pods are crushed and used as hair wash to remove } \\
\text { dandruff }\end{array}$ \\
\hline $\begin{array}{l}\text { Mikania micrantha Kunth } \\
\text { [Asteraceae]; GBP/NE/WM- } 08\end{array}$ & Climber & $\begin{array}{l}\text { Leaf paste is used in itching, skin diseases, headache; } \\
\text { cut and wound healing }\end{array}$ \\
\hline $\begin{array}{l}\text { Musa sapientum L. [Musaceae]; Kopak; } \\
\text { GBP/NE/OP-54 }\end{array}$ & Herb & Juice of the Pseudo-stem in Diarrhoea, dysentery \\
\hline $\begin{array}{l}\text { Oxalis corniculata L. [Oxalidaceae]; } \\
\text { GBP/NE/OP-26 }\end{array}$ & Herb & $\begin{array}{l}\text { Shoot used as Appetizer, headache, Relieves } \\
\text { intoxication from wine; Diarrhoea }\end{array}$ \\
\hline $\begin{array}{l}\text { Paederia foetida L. [Rubiaceae]; Yepe- } \\
\text { tere; GBP/NE/WM-19 }\end{array}$ & Climber & $\begin{array}{l}\text { Stem is boiled and used in gastritis, diarrhoea, } \\
\text { dysentery, stomach disorder, paste of leaves applied to } \\
\text { skin diseases }\end{array}$ \\
\hline $\begin{array}{l}\text { Paris polyphylla Sm. [Liliaceae] } \\
\text { GBP/NE/OP-18 }\end{array}$ & Herb & $\begin{array}{l}\text { Decoction of the rhizome is used in Piles, constipation } \\
\text { and high fat }\end{array}$ \\
\hline $\begin{array}{l}\text { Phoebe cooperiana P.C. Kanj. \& Das } \\
\text { [Lauraceae]; Tapir, GBP/NE/WM-34 }\end{array}$ & Tree & Bark paste is for wounds and boils, itching \\
\hline $\begin{array}{l}\text { Polygonum barbatum L. } \\
\text { [Polygonaceae]; Rukji; GBP/NE/WM- } \\
14\end{array}$ & Herb & $\begin{array}{l}\text { Paste of the leaves applied to ringworm and other skin } \\
\text { diseases }\end{array}$ \\
\hline $\begin{array}{l}\text { Pothos scandens L. [Araceae]; Lomang- } \\
\text { loset; GBP/NE/WM-30 }\end{array}$ & Climber & $\begin{array}{l}\text { Stem and leaf paste are used in treatment of Bone } \\
\text { fracture }\end{array}$ \\
\hline $\begin{array}{l}\text { Pouzolzia bennettiana Wight } \\
\text { [Urticaceae]; Oyik; GBP/NE/WM-33 }\end{array}$ & Herb & $\begin{array}{l}\text { Leaves in the cooked form as vegetable is used in } \\
\text { Dysentery }\end{array}$ \\
\hline $\begin{array}{l}\text { Psidium guajava L. [Myrtaceae]; } \\
\text { Muduri; GBP/NE/OP-52 }\end{array}$ & Tree & Leaves in the raw form are eaten in Diarrhoea \\
\hline $\begin{array}{l}\text { Rauvolfia densiflora Benth } \\
\text { [Apocynaceae]; Ruki; } \\
\text { GBP/NE/WM-40 }\end{array}$ & Shrub & $\begin{array}{l}\text { Decoction of root, bark and seeds in equal quantity } \\
\text { diluted with water }(3: 2) \text { is administered orally to cure } \\
\text { malaria }\end{array}$ \\
\hline $\begin{array}{l}\text { Spilanthes acmella (L.) L. [Asteraceae]; } \\
\text { Marbang/Marsang; GBP/NE/OP-04 }\end{array}$ & Herb & Raw inflorescence is used in toothache \\
\hline $\begin{array}{l}\text { Solanum spirale Roxb. [Solanaceae]; } \\
\text { Bangko; GBP/NE/OP-12 }\end{array}$ & Shrub & $\begin{array}{l}\text { Fruits and leaves in the raw form or boiled form are } \\
\text { used in the cuts and wounds, stomach-ache }\end{array}$ \\
\hline
\end{tabular}


Ethnomedicinal plants of Adi community

\begin{tabular}{|l|l|l|}
\hline $\begin{array}{l}\text { Botanical name [Family]; } \\
\text { Local name; Voucher specimen }\end{array}$ & Habit & Traditional uses \\
\hline $\begin{array}{l}\text { Solanum torvum Sw. [Solanaceae]; } \\
\text { Aying tanyum; GBP/NE/OP-45 }\end{array}$ & Shrub & $\begin{array}{l}\text { Smoke inhalation or direct use of the fruit is used in } \\
\text { Toothache }\end{array}$ \\
\hline $\begin{array}{l}\text { Trichosanthes cordata Roxb. } \\
\text { [Cucurbitaceae]; Dongkoriyong; } \\
\text { GBP/NE/WM-27 }\end{array}$ & Climber & Decoction of the root is used in Dysentery, diarrhoea \\
\hline $\begin{array}{l}\text { Zanthoxylum rhetsa (Roxb.) DC. } \\
\text { [Rutaceae]; Onger; GBP/NE/WM-23 }\end{array}$ & Shrub & Leaves are boiled and used in Jaundice, fever, headache \\
\hline $\begin{array}{l}\text { Zingiber zerumbet (L.) Roscoe ex Sm. } \\
\text { Zingiberaceae]; Kekir; GBP/NE/OP-20 }\end{array}$ & Herb & $\begin{array}{l}\text { Decoction of the rhizome is used in Stomach-ache, } \\
\text { diarrhoea, cough }\end{array}$ \\
\hline
\end{tabular}

\section{Utilization pattern of different species for treatment of diseases}

These plants were used by the local people and traditional medicinal practitioners (TMP) to treat different types of minor and major ailments including cuts and wounds, cold, fever including malarial fever, cough, gastrointestinal problem, pain reliever, diabetes, cancer and other diseases. The diseases treated were categorised into 10 different groups (Table 2). Maximum number of species were being used for treatment of gastrointestinal disorders, dermatological disorder and general health (Figure 5). In terms of number of uses for each species, Bidens pilosa was ranked first, being used for treatment of maximum number of ailments (7 categories), followed by Artemisia nilagirica being used in 4 ailment categories. Zanthoxylum rhetsa, Aconitum heterophyllum, A. ferox and Drymaria cordata were used for treating 3 different types of ailments, while the remaining species were reported to be used in 2 different types of ailments or lesser (Figure 6).

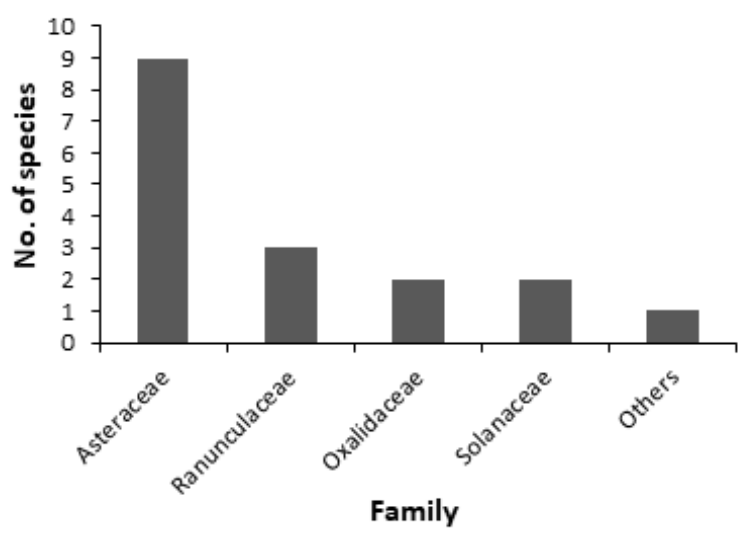

Figure 3. Family-wise representation of ethnomedicinal plants reported from the study area (Others $=$ families with only 1 species): Lamiaceae, Apiaceae, Apocynaceae, Araceae, Asparagaceae, Begoniaceae, Caricaceae, Caryophyllaceae, Cucurbitaceae, Fagaceae, Lauraceae, Leguminosae, Liliaceae, Mimosaceae, Musaceae, Myrsinaceae, Myrtaceae, Polygonaceae, Rubiaceae, Rutaceae, Urticaceae, Zingiberaceae)

\section{Plant parts used, mode of preparation and administration}

The most frequently used plant parts for the preparation of medicine were leaves, followed by roots and rhizomes, seeds and shoot part. Flowers were the least used plant part for medicine preparation and was reported only from one species (Figure 7). The mode of preparation and administration of the medicines varies according to the nature of ailment treated. The most common forms of medicinal preparations were paste form followed by 
Table 2. Categorisation of traditional medicinal uses

\begin{tabular}{|l|l|}
\hline $\begin{array}{l}\text { Category of } \\
\text { ailment }\end{array}$ & \multicolumn{1}{|c|}{ Diseases/disorders } \\
\hline General health & $\begin{array}{l}\text { Headache, high blood pressure, insomnia, dental care, hair care, health } \\
\text { tonic }\end{array}$ \\
\hline Gastrointestinal & $\begin{array}{l}\text { Appetizer, Gastritis, indigestion, vomiting, piles, stomach disorder, } \\
\text { diarrhoea, cholera, dysentery, ulcer, Intestinal worm }\end{array}$ \\
\hline Dermatological & Antiseptic/cut and wounds, boils, allergic swelling, Burns, Ringworm \\
\hline Musculo-skeletal & Bone fracture, toothache, body pain, sprain, headache, rheumatism, ulcer \\
\hline Respiratory & Cold, cough, asthma \\
\hline Genito-urinary & Gynaecological disorder, urinary tract infection, etc \\
\hline $\begin{array}{l}\text { Eye, ear, nose } \\
\text { ailments }\end{array}$ & Eye and ear infection, sinusitis, nose bleed \\
\hline Snake/insect bites & Snake bites, leech bites \\
\hline Fever & General fever, malaria, typhoid fever \\
\hline Liver disorders & Hepatitis, Jaundice \\
\hline
\end{tabular}

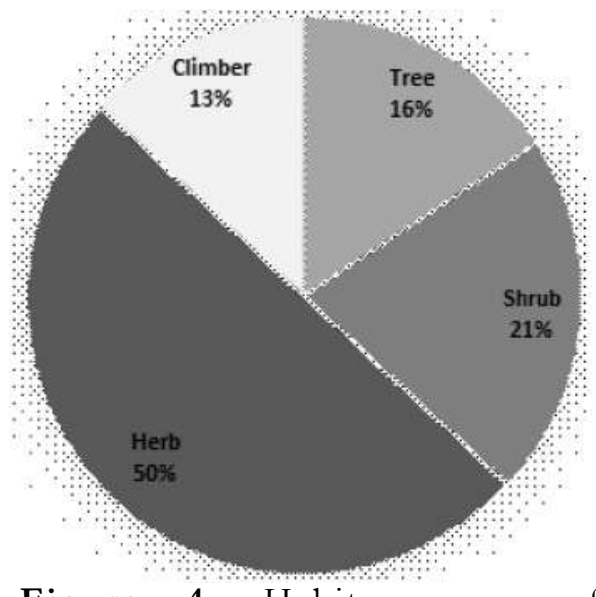

Figure 4. Habit groups of ethnomedicinal plant species reported from the study area

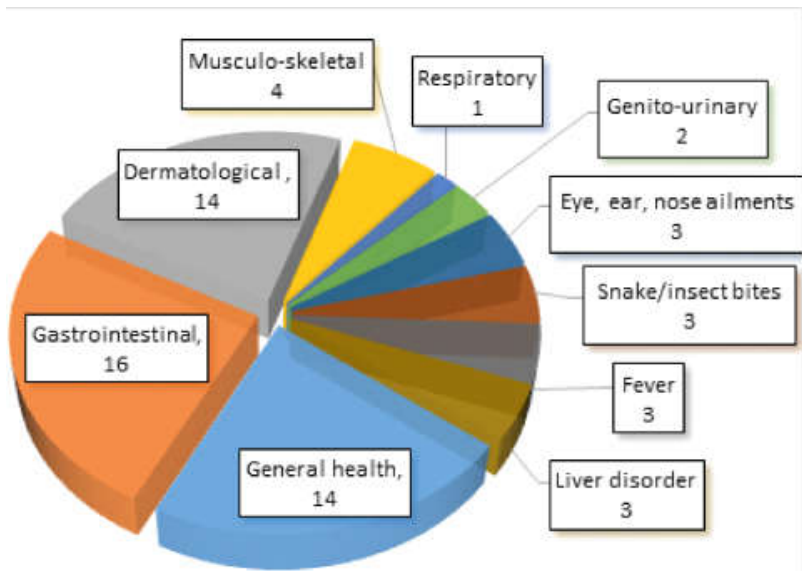

Figure 5. Traditional use categories of medicinal plants from the study area

cooked, raw (direct consumption) and as decoction (Figure 8). Other forms of usage such as juice of leaves and fruits and smoke/steam inhalation were also observed for few species and ailments such as toothache and respiratory problems. The common use of medicinal plants in paste form suggested that fresh plant material were frequently used. This was further confirmed through field observation and interaction with the informants who revealed that they prefer to collect plants from the wild only when necessary and in required quantity. However, for some seasonal species and those species which were not commonly available near the village, the useful plant parts were collected during the growing season, dried and stored for later use. During field survey, it was observed that roots and rhizomes of Aconitum spp., Campylandra aurantiaca, Coptis teeta and Paris polyphylla were preserved by local people in dried form and kept over the fire-place for long storage. The use of fresh materials has its advantages as it prevents deterioration of volatile compounds, the concentration of which may be reduced by drying. 


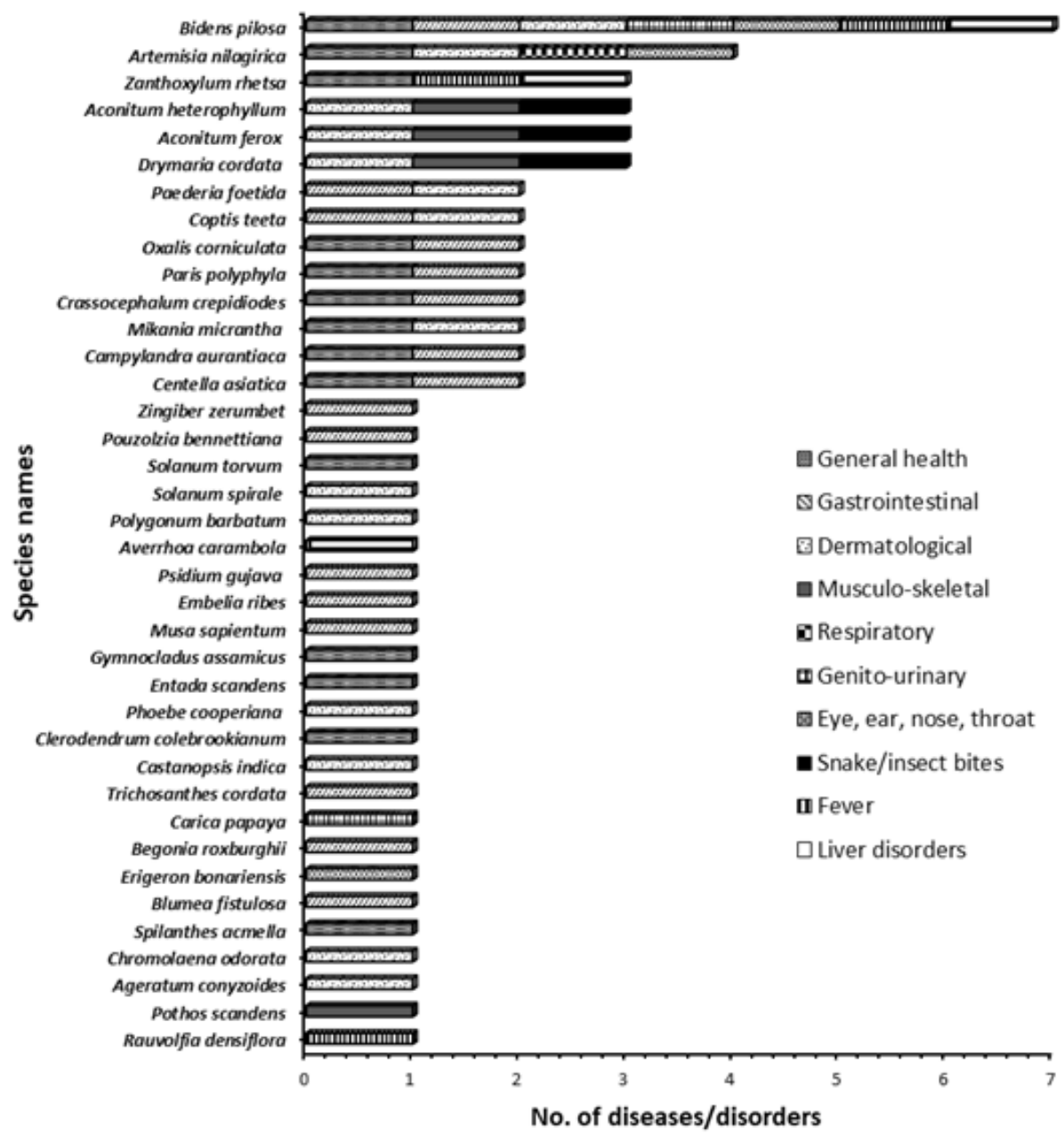

Figure 6. Ranking of species on the basis of their usage for treatment of different categories of ailments

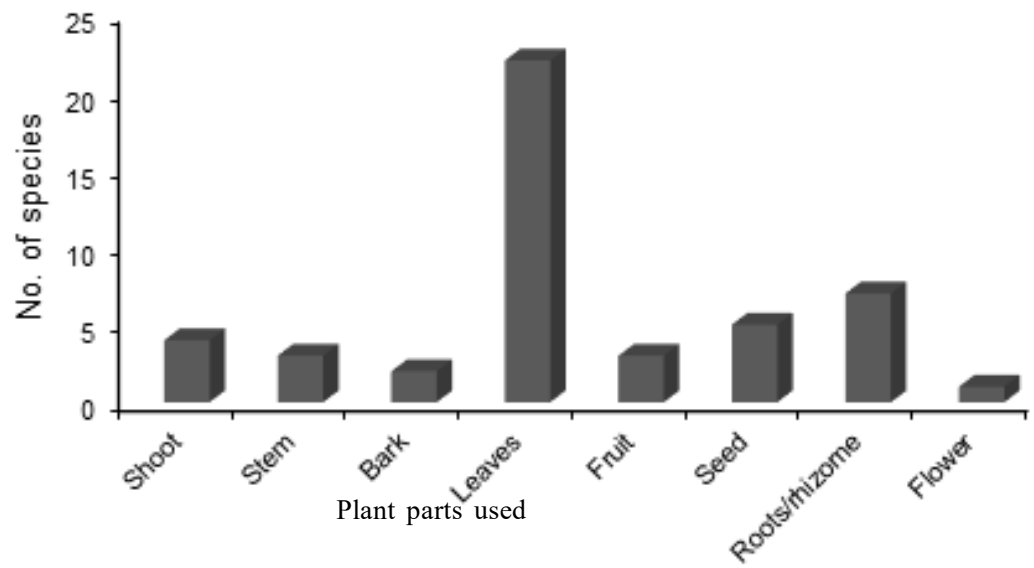

Figure 7. Plant parts used for preparation of traditional medicine 


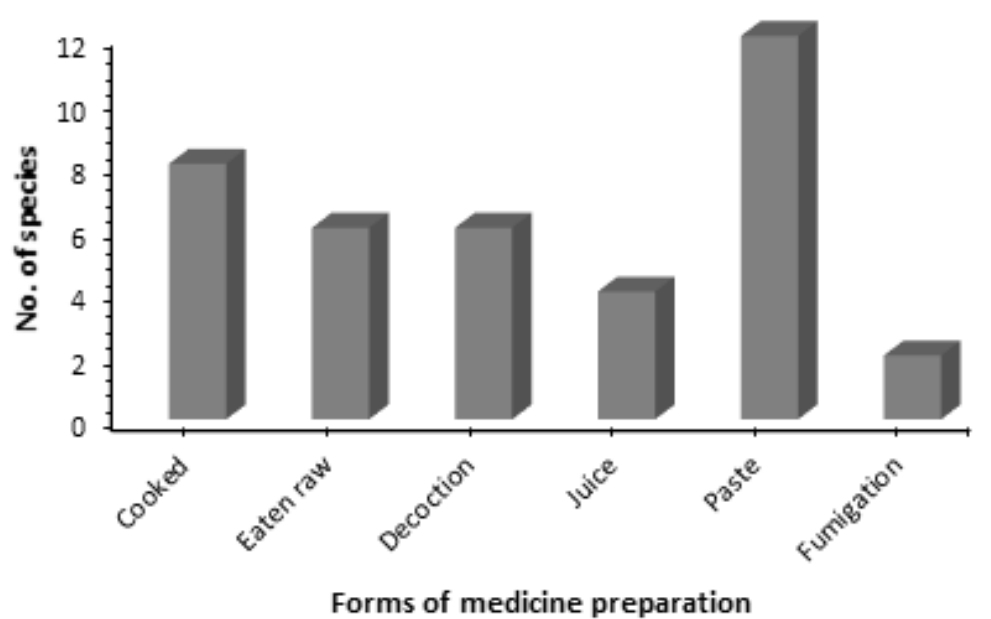

Figure 8. Different forms of medicine preparation from ethnomedicinal plant species

The mode of medicine administration varies depending on the nature of ailment and part of the body affected. For external ailments like dermatological problems, wounds, bone fracture, body pain, toothache, etc., the crushed or ground paste is applied directly on the affected area. For internal ailments such as gastrointestinal problems, fever, headache, the medicine can be administered orally in raw or cooked form, water suspension and decoction. However, there was a lack of specific dosage for administration and the amount to be taken varies depending on the age of the individual as well as on the severity of the ailment and as advised by the concerned local medicinal practitioner. This may be considered as a disadvantage of the traditional medicinal practices which needs to be addressed through scientific studies to determine the correct doses, side effects and contraindications of different medicinal preparations.

\section{DISCUSSION}

A number of plant species reported in the present study have also been mentioned by other researchers being used by the Adi community residing in different areas of East Siang district (Baruah et al. 2013; Das et al. 2013; Payum et al. 2015a) and few villages of Upper Siang district (Kagyung et al. 2010), which were located close to our study area. This suggested that these plant species are widely utilised as medicine among the indigenous communities of this region and there might be a pre-existing mechanism of knowledge sharing between the people of different villages regarding the cross-cultural uses of these ethnomedicinal plants. The member of Asteraceae has been reported as the most dominant medicinal plants in the northeastern region of India (Haridasan et al. 2003). In agreement with our results, dominance of medicinal plants of Asteraceae was also reported by Jeyaprakash et al. (2017) in their study in East Siang district of Arunachal Pradesh. The wide use of herbaceous plants as medicine may be mainly due to the relatively easy availability of herbs in the study area compared to shrubs and trees as observed during our field survey. A few plants recorded in the present study including Ageratum conyzoides, Chromolaena odorata and Spilanthes acmella have also been reported to be widely used in traditional medicine in other parts of the world such as Africa, Asia, and South America for treatment of various diseases (Dubey et al. 2013, Kamboj \& Saluja 2008, Pandith et al. 2013). Paris polyphylla is a well-known folk medicinal herb commonly used in Traditional Chinese Medicine for hundreds of years (Bureau of Chinese Herb Administration, 1999) and an important herbal drug for the treatment of inflammation, fractures, parotitis, hemostatis, snake bite and abscess in folk medicine (Wu et al. 2012). Kagyung et al. (2010) reported that Campylandra 
aurantiaca and Coptis teeta were the most commonly used medicinal plants among the Adi community residing in the Dehang-Dibang Biosphere Reserve area of Arunachal Pradesh. In fact, C. aurantiaca has been mentioned by Gajurel et al. (2015) as one of the high value medicinal plants of Arunachal Pradesh. Other species such as Pouzolzia bennettiana, Zanthoxylum rhetsa and Phoebe cooperiana are one of the most preferred wild vegetable and fruit plants among the indigenous communities of Arunachal Pradesh and found to sold in the local markets (Payum et al. 2013a, 2013b, 2015b).

\section{CONCLUSION}

The present study revealed that the practice of traditional medicine is still an integral part of the people of the study area, especially in remote villages where accessibility to modern healthcare services are limited. However, recently there has been a decline in the traditional knowledge and lack of interest were witnessed among the younger generations due to the loss of direct contact and association with nature. This has posed a threat on the very existence of such valuable traditional knowledge system. Therefore, detailed research and documentation is urgently needed to identify important species of ethnomedicinal plants used by different communities of the state. Many of the ethnomedicinal plants recorded in the present study were found to possess a variety of pharmacological properties and bioactive compounds which further supported their use in traditional healthcare practices. Lack of integrated approach for studies on ethnomedicinal plants, pharmacology and phytochemistry, especially from this region, provides a greater opportunity for further venturing research on the phytochemical and pharmacological aspects of these ethnomedicinally important species. The resultant knowledge would also be useful for addressing conservation priorities and value-addition of the selected species for the benefit of the indigenous communities.

\section{Acknowledgements}

The authors are thankful to Director, G.B. Pant National Institute of Himalayan Environment, for providing the facilities required for carrying out the research work. Financial support from the Ministry of Environment, Forests \& Climate Change, Govt. of India, for In-house Project (Project No. 09) is gratefully acknowledged. The authors are also grateful to the indigenous communities of the study area for their support during field surveys and plant material collection.

\section{LITERATURE CITED}

Arya, O.P.; Pandey, A. \& Samal, P.K. 2017. Ethnobotany and nutritional importance of four selected medicinal plants from Eastern Himalaya, Arunachal Pradesh. Journal of Medicinal Plants Studies 5(1): 45 - 49.

Baruah, S.; Borthakur, S. K.; Gogoi, P. \& Ahmed, M. 2013. Ethnomedicinal plants used by Adi-Minyong tribe of Arunachal Pradesh, Eastern Himalaya. Indian Journal of Natural Products and Resources 4(3): $278-282$.

Bureau of Chinese Herb Administration. 1999. Chinese Herbal Med. Shanghai: Shanghai Science and Technology Publishing Co.

Chakraborty, R.; De, B.; Devanna, N. \& Sen, S. 2012. North-East India an Ethnic Storehouse of Unexplored Medicinal Plants. Journal of Natural Products and Plant Resources 2(1): 143 - 152.

Choudhary, R.K.; Srivastava, R.C.; Das, A.K. \& Lee, J. 2012. Floristic diversity assessment and vegetation analysis of Upper Siang district of eastern Himalaya in North East India. Korean Journal of Plant Taxonomy 42(3): 222 - 246. 
Danggen, O.; Mello, J.; Ering, K.; Hussain, A. \& Saikia, V. 2018. Ethnomedicinal Plant Knowledge among the Adi Tribe of Yingkiong and Mariyang Valley, Upper Siang District, Arunachal Pradesh, India. International Journal of Pure \& Applied Biosciences 6 (1): 1504 - 1511.

Das, M.; Jaishi, A. \& Sarma, H. N. 2013. Traditional medicines of herbal origin practice by the Adi tribe of East Siang District of Arunachal Pradesh, India. Global Journal of Research in Medicinal Plants and Indigenous Medicine 2(5): 298 - 310.

Doley, B.; Gajurel, P.R.; Rethy, P.; Singh, B.; Buragohain, R. \& Potsangbam, S. 2010. Lesser known Ethno medicinal Plants Used by the Nyishi community of Papum Pare District, Arunachal Pradesh. Journal of Biosciences Research 1(1): $34-36$.

Dubey, S.; Maity, S.; Singh, M.; Saraf, S.A. \& Saha, S.; 2013. Phytochemistry, Pharmacology and Toxicology of Spilanthes acmella: A Review. Advances in Pharmacological Sciences, Article ID 423750, http://dx.doi.org/10.1155/2013/423750.

Gajurel, P.R.; Ronald, Kh.; Buragohain, R.; Rethy, P.; Singh, B. \& Potsangbam, S. 2015. On the present status of distribution and threats of high value medicinal plants in the higher altitude forests of the Indian Eastern Himalaya. Journal of Threatened Taxa 7(6): $7243-7252$.

Ghosh, G.; Ghosh, D.C.; Melkania, U. \& Majumdar, U. 2014. Traditional medicinal plants used by the $A d i$, Idu and Khamba tribes of Dehang-Debang Biosphere Reserve in Arunachal Pradesh. International Journal of Agriculture, Environment \& Biotechnology 7(1): 165 - 171.

Haridasan, K.; Anupam, S.; Bhuyan, L.R. \& Bisht, N.S. 2003. Medicinal plants sector in Arunachal Pradesh: an overview. Indian Forester 129: 37 - 47.

Jeyaprakash, K.; Lego, Y.J.; Payum, T.; Rathinavel, S. \& Jayakumar, K. 2017. Diversity of medicinal plants used by Adi community in and around area of D' Ering Wildlife Sanctuary, Arunachal Pradesh, India. World Scientific News 65: 135 - 159.

Johnson, T.P. 2014. Snowball sampling: Introduction. Wiley StatsRef: Statistics Reference Online, DOI: $10.1002 / 9781118445112$. stat05720.

Kagyung, R.; Gajurel, P.R. \& Singh, B. 2010. Ethnomedicinal plants used for gastro-intestinal diseases by Adi tribes of Dehang-Debang Biosphere Reserve in Arunachal Pradesh. Indian Journal of Traditional Knowledge 9(3): 496 - 501.

Kamboj, A. \& Saluja, A.K. 2008. Ageratum conyzoides L.: A review on its phytochemical and pharmacological profile. International Journal of Green Pharmacy 2(2): 59 - 68.

Myers, N.; Mittermeier, R.A.; Mittermeier, C.A.; da Fonseca, G.A.B. \& Kent, J. 2000. Biodiversity hotspots for conservation priorities. Nature 403: 853 - 858.

Pandith, H.; Zhang, X.; Liggett, J.; Min, K-W.; Gritsanapan, W. \& Baek, S.J. 2013. Haemostatic and wound healing properties of Chromolaena odorata leaf extract, ISRN Dermatology, http://dx.doi.org/10.1155/2013/168269.

Payum, T.; Das, A.K.; Shankar, R. \& Lego, Y.J. 2015a. 99 selected folk medicinal plants of East Siang District of Arunachal Pradesh, India. American Journal of PharmTech Research 5(1) $398-409$.

Payum, T.; Das, A.K.; Shankar, R.; Tamuly, C. \& Hazarika, M. 2013a. Ethnobotany and antioxidant determination of Phoebe cooperiana fruit-a highly utilized wild fruit in Arunachal Pradesh, India. International Journal of Pharmaceutical Sciences and Research 4(8): 3196 - 3201.

Payum, T.; Das, A.K.; Shankar, R.; Tamuly, C. \& Hazarika, M. 2013b. Folk use and antioxidant potential determination of Zanthoxylum rhetsa DC. Shoot -a highly utilized hot spice folk 
vegetable of Arunachal Pradesh, India. International Journal of Pharmaceutical Sciences and Research 4(12): 4597 - 4602.

Payum, T.; Das, A.K.; Shankar, R.; Tamuly, C. \& Hazarika, M. 2015b. Antioxidant potential of Pouzolzia bennettiana -a nutritious traditional food plant used in Arunachal Pradesh, India. Advanced Journal of Pharmacie and Life Science Research 3(2): 1 - 7.

Rao, R.R. \& Hajra, P.K. 1986. Floristic diversity of Eastern Himalaya in a conservation perspective. Proceedings of the Indian Academy of Science, 103 - 125.

Sati, P.; Pandey, A. \& Palni, L.M.S. 2012. Antimicrobial Potential of Leaf Extracts of Gink.go biloba L., growing in Uttarakhand, India. National Academy of Science Letters 35: 201 - 206.

Shankar, R. \& Rawat, M.S. 2008. Medicinal plants used in traditional medicine in Lohit and Dibang valley districts of Arunachal Pradesh. Indian Journal of Traditional Knowledge 7(2): $288-295$.

World Health Organization. 2001. General Guidelines for methodologies on research and evaluation of Traditional Medicine, WHO, Geneva, Switzerland, p.1.

Wu, S.; Gao, W.; Qiu, F.; Man, S.; Fu, S. \& Liu, C. 2012. Simultaneous quantification of Paris Polyphyllin D and Paris $\mathrm{H}$, two potential antitumor active components in Paris polyphylla by liquid chromatography-tandem mass spectrometry and the application to pharmacokinetics in rats. Journal of Chromatography B. 905: $54-60$. 